\title{
Strategies for molecular characterisation of methicillin- and gentamicin-resistant Staphylococcus aureus in a Canadian nosocomial outbreak
}

\author{
N. BIGELOW, L.-K. NG, H. G. ROBSON* and J. R. DILLON $†$ \\ Antimicrobials and Molecular Biology Division, Laboratory Centre for Disease Control, Ottawa, Ontario, and \\ *The Royal Victoria Hospital, 687 Avenue des Pins Ouest, Montréal, Québec, Canada
}

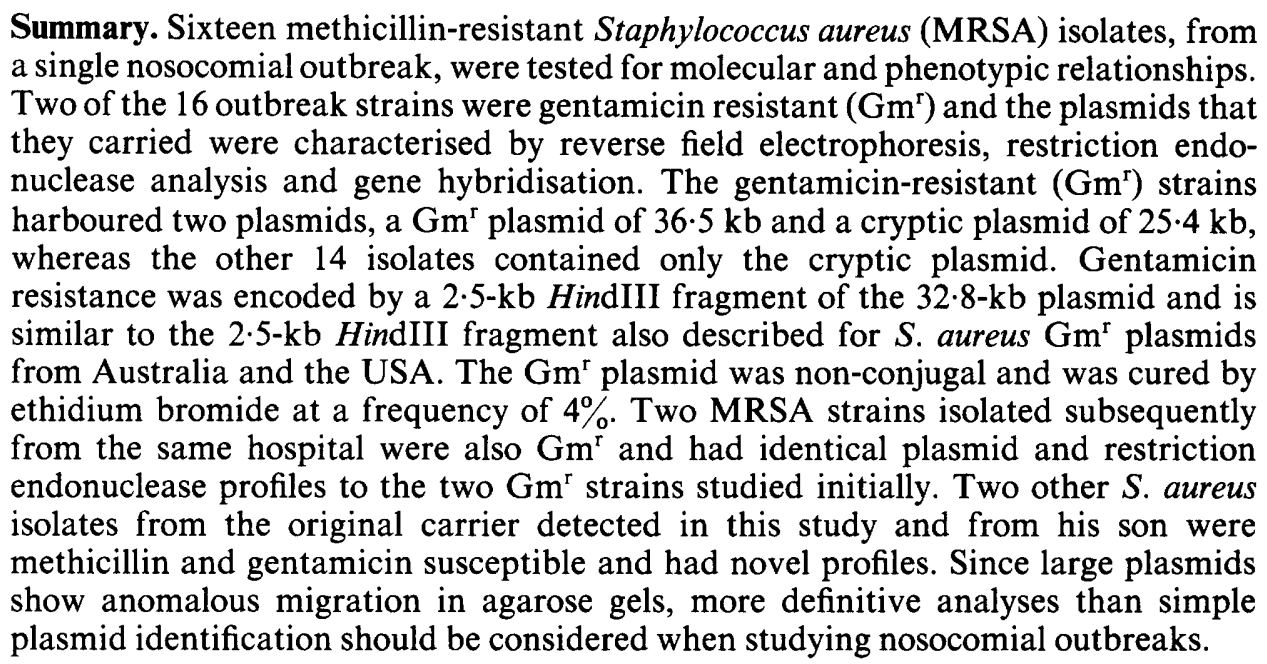

\section{Introduction}

During the late 1960 s to early 1970 s, methicillinresistant Staphylococcus aureus (MRSA) strains were reported in many countries (Borowski et al., 1964; Rountree and Beard, 1968; O'Toole et al., 1970; Parker and Hewitt, 1970; Kayser and Mak, 1972). Nosocomial outbreaks caused by gentamicin-resistant $\left(\mathrm{Gm}^{\mathrm{r}}\right)$ S. aureus were first observed in 1975 (Buckwold et al., 1979). Strains resistant to both gentamicin and methicillin, as well as to a wide range of other antibiotics, were first reported in Australia (Perceval et al., 1976) and England (Shanson et al., 1976). Multiresistant S. aureus strains have subsequently resulted in many other nosocomial outbreaks worldwide (Price et al., 1980; King et al., 1982; Wenzel 1982; Varaldo et al., 1984).

Gentamicin resistance in $S$. aureus has been

Received 31 Jan. 1989; accepted 22 Mar. 1989.

†Correspondence should be sent to Dr J. R. Dillon, Antimicrobials and Molecular Biology Division, Bureau of Microbiology, Laboratory Centre for Disease Control, Tunney's Pasture, Ottawa, Ontario, Canada K1A 0L2. shown to be mediated primarily by plasmids (18$57 \mathrm{~kb}$ ) which specify two aminoglycoside-modifying enzymes, aminocyclitol-2" -phosphotransferase and aminocyclitol-6'-acetyl-transferase [APH (2")AAC (6')I] (Shannon and Phillips, 1982). These enzymes also specify tobramycin and kanamycin resistance (Lyon and Skurray, 1987). The genes for the enzymes mediating gentamicin, tobramycin and kanamycin resistance were mapped to a $2 \cdot 5-\mathrm{kb}$ HindIII fragment on gentamicin-resistance plasmids. This HindIII fragment was sequenced and found to encode a single bifunctional protein of $59 \mathrm{Kda}$ (Rouch et al., 1987). Both the gentamicinresistance genes and methicillin-resistance determinants in some $S$. aureus strains have been located on transposons (Lyon et al., 1984; Trees and Iandolo, 1988).

Because plasmid profiles and methicillin resistance in $S$. aureus have not been well characterised or documented in Canada, we investigated 18 MRSA isolates from a Canadian outbreak. Their plasmid content and the restriction endonuclease patterns of their plasmids were determined and compared with $S$. aureus plasmids reported from 
other outbreaks. The nature of gentamicin resistance in these strains was also examined with a specific DNA probe because, apart from a recent study (Kreiswirth et al., 1988), $\mathrm{Gm}^{\mathrm{r}}$ plasmids in MRSA have not been investigated in Canadian strains.

\section{Materials and methods}

\section{Bacterial strains and growth}

Eighteen clinical methicillin-resistant strains of $S$. aureus (Royal Victoria Hospital, Montréal, Québec) were analysed. Sixteen of the strains (SA1-SA16) were isolated in an initial outbreak, and as a follow-up several months later, two further strains (SA17 and SA18) from the same hospital were investigated. We also examined two methicillin-susceptible strains (SA19 and SA20) isolated from the original carrier and his son.

Other strains used in mating and hybridisation studies are listed in table I. Chromosomal antibiotic resistance markers for strain RN450 were selected by spontaneous mutation on Tryptone Soya Agar (TSA) (Oxoid Ltd, Nepean, Ont., Canada) containing rifampicin $1000 \mathrm{mg} /$ L.

$S$. aureus isolates were routinely subcultured on TSA. Strains for mating studies were grown on Brain Heart Infusion (BHI) agar or in BHI Broth (Difco Laboratories, Detroit, MI, USA). Antibiotics used for mating experiments were purchased from Sigma (St Louis, MO, USA).

\section{Identification and antimicrobial susceptibility testing}

Antimicrobial susceptibilities of $S$. aureus strains were determined by the disk diffusion method outlined by Thornsberry (1984). The plates were incubated at $35^{\circ} \mathrm{C}$ and, after $24 \mathrm{~h}$, the zones of inhibition were measured. Standard disks (General Diagnostics, Warner-Lambert Co., Morris Plains, NJ, USA) for the following antibiotics were used: penicillin, erythromycin, oxacillin, methicillin, clindamycin, amikacin, gentamicin, cephalothin, vancomycin, chloramphenicol, tetracycline, and tobramycin. Strains were classified as resistant according to the recommendations of the National Committee for Clinical Laboratory Standards (1984).

\section{Isolation of plasmid DNA and gel electrophoresis}

Rapid lysis and extraction of plasmid DNA from isolates was accomplished by the method of Birnboim and Doly (1979) with the modification that cells were incubated initially for $30 \mathrm{~min}$ at $37^{\circ} \mathrm{C}$ in lysostaphin (Sigma) $0.5 \mathrm{~g} / \mathrm{L}$ and ribonuclease A (Boehringer Mannheim Canada Ltd, Dorval, Qué., Canada) $10 \mathrm{~g} / \mathrm{L}$.

Plasmid DNA for restriction endonuclease analysis was obtained by pooling cells from four TSA plates and by lysing them according to a scaled-up modification of the Birnboim and Doly procedure ( $\mathrm{Ng}$ et al., 1987). DNA was then purified on caesium chloride density gradients (Maniatis et al., 1982); the plasmid band was isolated and ethidium bromide was extracted with isobutanol as described by Dillon et al. (1985).

Screening of plasmid DNA was performed on agarose (BIORAD, Mississauga, Ont., Canada) $0.7 \%$ gels in

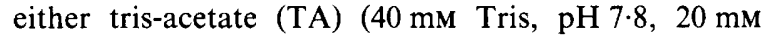
sodium acetate, $1.8 \mathrm{~mm}$ EDTA) or tris-borate (TBE) (89 mM Tris, pH 8.3, $89 \mathrm{~mm}$ boric acid, $25 \mathrm{~mm} \mathrm{Na}$ EDTA) buffer. Gels were electrophoresed for approximately $3 \mathrm{~h}$ at $80 \mathrm{~V}$.

Field inversion electrophoresis (Carle et al., 1986) was performed with a PP1-100 programmable power inverter (MJ Research Inc., Cambridge, MA, USA). Program 2 (5-6 volts $/ \mathrm{cm}$ ) was employed on agarose $0.8 \%$ gels in $0.5 \times$ TBE at room temperature for approximately $5 \mathrm{~h}$. Gels

Table I. Bacterial strains used in mating and hybridisation studies

\begin{tabular}{|c|c|c|c|c|}
\hline Species & Strain & Phenotype & Plasmids & Source \\
\hline S. aureus & RN450 & $\begin{array}{l}\text { nonlysogenic derivative of } \\
\text { S. aureus NCTC } 8325 \\
\text { phage-free recipient }\end{array}$ & none & $\begin{array}{l}\text { Dr R. P. Novick (Nov- } \\
\text { ick, 1967) }\end{array}$ \\
\hline S. aureus & RN450SR & $\begin{array}{l}\mathrm{Sm}^{\mathrm{r}} \text { and } \mathrm{Rif}^{\mathrm{r}} \text { mutant of } \\
\mathrm{RN} 450 \text { recipient }\end{array}$ & none & This laboratory \\
\hline S. epidermidis & UM899 & $\begin{array}{l}\mathrm{Gm}^{r} \mathrm{Em}^{r} \mathrm{Tc}^{r} \mathrm{Pc}^{r} \mathrm{Cc}^{r} \mathrm{Clinical} \\
\text { isolate, control donor }\end{array}$ & $\begin{array}{l}\text { PAM899-1 } \\
\text { PAM899-2 } \\
\text { PAM899-3 }\end{array}$ & $\begin{array}{l}\text { Dr D. Schaberg (Forbes } \\
\text { and Schaberg, 1983) }\end{array}$ \\
\hline S. aureus & 879R4RF & $\begin{array}{l}\text { Phage-free Rif }{ }^{r}, \text { Fus }^{r} \text { Re- } \\
\text { striction deficient, modifica- } \\
\text { tion deficient recipient }\end{array}$ & none & $\begin{array}{l}\text { Dr D. Schaberg (Forbes } \\
\text { and Schaberg, 1983) }\end{array}$ \\
\hline E. coli & RN6189 & $\mathrm{Gm}^{\mathrm{r}} \mathrm{Pc}^{\mathrm{r}}$ & $\mathrm{pH} 13$ & $\begin{array}{l}\text { Dr B. Kreiswirth (Dick- } \\
\text { giesser and Kreiswirth, } \\
\text { 1986) }\end{array}$ \\
\hline
\end{tabular}

Rif, rifampicin; Sm, streptomycin; Gm, gentamicin; Em, erythromycin; Tc, tetracycline; Pc, penicillin; $\mathrm{Cc}$, clindamycin; Fus, fusidic acid. 
were stained with ethidium bromide (Sigma) $0 \cdot 1 \mathrm{mg} / \mathrm{L}$ and DNA bands were visualised on a UV transilluminator (Fotodyne, New Berlin, WI, USA).

\section{Restriction endonuclease analysis}

Restriction endonuclease digestions of DNA were performed as recommended by the supplier (Boehringer Mannheim Canada Ltd). Restricted DNA was resolved on horizontal agarose $0.7 \%$ gels for $18 \mathrm{~h}$ at $40 \mathrm{~V}$ with TBE buffer.

\section{DNA hybridisation}

DNA from agarose gels was transferred to nitrocellulose sheets by the method of Southern (1975). The Southern blot was hybridised with the $2 \cdot 1-\mathrm{kb}$ DdeI fragment of $\mathrm{pH} 13$ (Dickgiesser and Kreiswirth, 1986) which was used as a probe for gentamicin resistance and was extracted from low melting-point agarose (Gibco BRL, Burlington, Ont., Canada) after gel electrophoresis (Ogden and Adams, 1987). The DNA fragment was precipitated in 2 volumes of $95 \%$ ethanol at $-20^{\circ} \mathrm{C}$.

Hybridisation was performed at $68^{\circ} \mathrm{C}$ for $18-24 \mathrm{~h}$ as described by Zoller et al. (1985). DNA (gentamicin resistant; $\mathrm{Gm}^{\mathrm{r}}$ probe) was labelled by nick translation (Maniatis et al., 1982; Dillon et al., 1985) with [ $\alpha-32$ P] dATP (ICN Radiochemicals, Irvine, CA, USA) that had a specific activity of $4500 \mathrm{Ci} / \mathrm{mmol}$. Approximately $1 \times$ $10^{6} \mathrm{cpm}$ was used for each blot.

\section{Mating and curing procedures}

Filter matings were performed by the method of Forbes and Schaberg (1983). The ratio of donor: recipient was adjusted to $1: 1$ or $1: 2$, and filters (Gelman GA-6, Ann Arbor, MI, USA) were incubated for $24 \mathrm{~h}$. Putative donors $\mathrm{SA} 1\left(\mathrm{Pc}^{\mathrm{r}}\right)$ and $\mathrm{SA} 2\left(\mathrm{Gm}^{\mathrm{r}}\right)$ were each mated with recipients RN450SR and 879R4rf (table I). Transconjugants were selected on BHI agar containing the appropriate antibiotics: rifampicin $25 \mathrm{mg} / \mathrm{L}$, fusidic acid $25 \mathrm{mg} / \mathrm{L}$, gentamicin $10 \mathrm{mg} / \mathrm{L}$, streptomycin $1000 \mathrm{mg} / \mathrm{L}$ and penicillin $\mathrm{G} 10 \mathrm{mg} /$ L (Forbes and Schaberg, 1983).

Curing procedures were performed by inoculating an overnight culture of $S$. aureus SA1 or SA2 $(0.2 \mathrm{ml})$ into $5.0 \mathrm{ml}$ of Tryptone Soya Broth (Oxoid) containing various concentrations of ethidium bromide $(50,100,150,200$, 300 or $400 \mathrm{mg} / \mathrm{L}$ ) and incubating them at $37^{\circ} \mathrm{C}$, overnight. Growth from the highest concentration of ethidium bromide which produced visible turbidity was plated on TSA and incubated at $37^{\circ} \mathrm{C}$ for $18-24 \mathrm{~h}$. One hundred colonies were randomly selected and inoculated on to TSA, and TSA containing the appropriate antibiotics (penicillin for SA1, gentamicin for SA2). The plates were then incubated for $24 \mathrm{~h}$ at $37^{\circ} \mathrm{C}$. The rate of cure was calculated as the percentage of antibiotic-sensitive colonies in the total colonies screened. Gentamicin-sensitive $\left(\mathrm{Gm}^{\mathrm{s}}\right)$ strains were lysed and their plasmid profiles were compared to those of the $\mathrm{Gm}^{\mathrm{r}}$ strains.

\section{Results}

\section{Antimicrobial susceptibilities}

Antimicrobial susceptibility patterns of the MRSA strains are shown in table II. Strains SA1, SA3-7 and SA9-16 had the same resistance pattern, which differed from SA2 and SA8 only by the additional presence of oxacillin and gentamicin resistance determinants. Resistance to oxacillin was present only in the pattern represented by strain SA1 and resistance to gentamicin only in the pattern represented by strain SA2. The patterns of the two $\mathrm{Gm}^{\mathrm{r}}$ strains which had been isolated subsequently (SA17, SA18) were similar to the SA2 pattern except that both were resistant to tobramycin; strain SA17 carried an oxacillin resistance determinant. Strains SA19 and SA20 had unique patterns. As with all of the other strains studied, SA19 and SA20 were resistant to penicillin but, unlike the other strains, SA19 was susceptible to all other antibiotics tested and SA20 was the only strain resistant to tetracycline.

\section{Plasmid analysis with different buffers and electrophoresis conditions}

Plasmid profiles of MRSA strains obtained by gel electrophoresis in TA and TBE buffer systems were different. These results are summarised with $S$. aureus strain $\mathrm{SA} 1$, representative of a $\mathrm{Gm}^{\mathrm{s}}$ MRSA (fig. 1, lanes $1 \mathrm{~A}$ and 2A), and with strain SA2, representative of a $\mathrm{Gm}^{\mathrm{r}}$ MRSA (fig. 1, lanes $1 B$ and $2 B$ ). With TBE buffer, only one plasmid band was visualised in each strain (fig. 1, lanes $2 \mathrm{~A}$ and $2 \mathrm{~B}$ ). Electrophoresis in TA buffer produced two and four bands for $\mathrm{Gm}^{\mathrm{s}}$ and $\mathrm{Gm}^{\mathrm{r}}$ strains respectively (fig. 1, lanes $1 \mathrm{~A}$ and $1 \mathrm{~B}$ ). In addition, the plasmid bands ran differently with respect to

Table II. Susceptibility patterns of representative $S$. aureus strains from outbreak

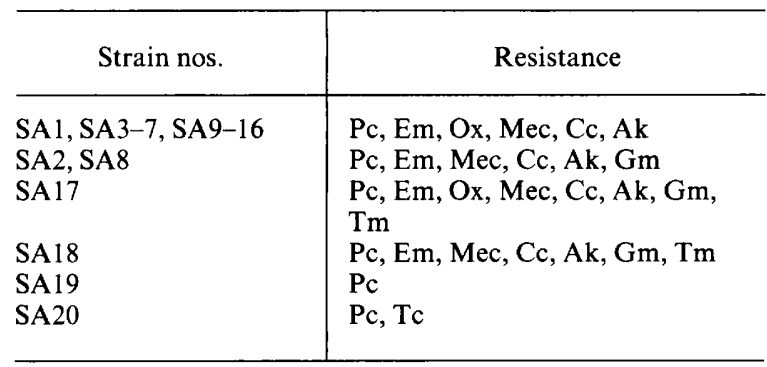

Pc, penicillin; Em, erythromycin; Ox, oxacillin; Mec, methicillin; Cc, clindamycin; Ak, amikacin; Gm, gentamicin; Tm, tobramycin 


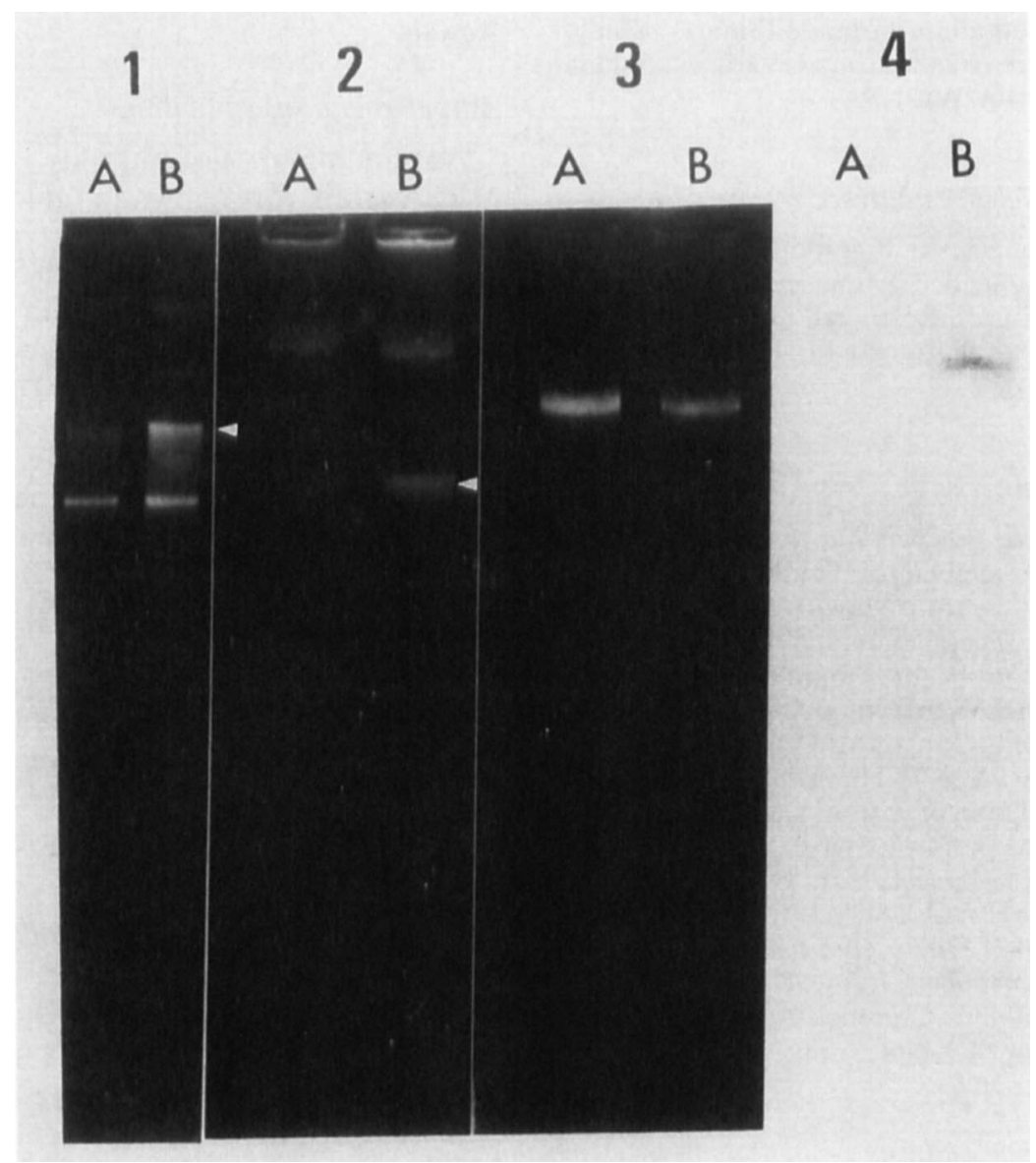

Fig. 1. Agarose gel electrophoresis of $\mathrm{Gm}^{\mathrm{s}}$ and $\mathrm{Gm}^{\mathrm{r}} \mathrm{MRSA}$ strains. Lane A, $\mathrm{Gm}^{\mathrm{s}}$ strain SA1; lane B: Gm ${ }^{\mathrm{r}}$ strain SA2. Gel 1, agarose $0.75 \%$ gel in TA buffer; gel 2, agarose $0.75 \%$ gel in TBE buffer; gel 3, agarose $0.8 \%$ gel in TBE buffer with reverse field electrophoresis; gel 4, autoradiograph of gel 3 blotted to nitrocellulose and probed with $32 \mathrm{P}-\mathrm{labelled} 2 \cdot 1-\mathrm{kb}$ DdeI fragment of pH13 coding for gentamicin resistance. White triangles represent chromosomal DNA.

chromosomal DNA (fig. 1). These anomalous results were resolved by reverse field electrophoresis and by restriction endonuclease analysis. Plasmid DNA was prepared in caesium chloride gradients and subsequent reverse field gel electrophoresis revealed one band for the $\mathrm{Gm}^{\mathrm{s}}$ strain SA1 (fig. 1, lane 3A) and two for $\mathrm{Gm}^{\mathrm{r}}$ strains SA2 (fig. 1, lane 3B). Plasmids resolved by reverse field electrophoresis (fig. 1, lanes $3 \mathrm{~A}$ and $3 \mathrm{~B}$ ) were blotted on to nitrocellulose and probed with the $2 \cdot 1-\mathrm{kb}$ DdeI fragment of $\mathrm{pH} 13$ which carried gentamicinresistance determinants. Only the larger plasmid band for $\mathrm{Gm}^{\mathrm{r}}$ strain SA2 hybridised with the probe (fig. 1, lane 4B) indicating that it was responsible for gentamicin resistance as well as eliminating the possibility that it (fig. 1, lane 3B) represented the open circular form of the lower band.

Restriction endonuclease analysis of total plasmid DNA with HindIII and PstI confirmed that the plasmid profiles of $\mathrm{Gm}^{\mathrm{s}}$ and $\mathrm{Gm}^{\mathrm{r}}$ strains were different (fig. 2) and also allowed definitive sizing of the two plasmids. These results showed that 18 MRSA strains, including the four $\mathrm{Gm}^{\mathrm{r}}$ strains, shared a common cryptic plasmid of $25.4 \mathrm{~kb}$. The four $\mathrm{Gm}^{\mathrm{r}}$ strains also carried a larger plasmid $(32.8 \mathrm{~kb})$. The plasmid size was determined by averaging the sum of the HindIII fragment sizes of four total plasmid DNA digests (table III). The PstI fragments were not used because the largest fragment could not be accurately sized with our markers (table III). In lanes with both the $25 \cdot 4$ - and $32 \cdot 8-\mathrm{kb}$ plasmids, the small cryptic plasmid could be distinguished visually from the $32 \cdot 8-\mathrm{kb} \mathrm{Gm}^{\mathrm{r}}$ plasmid by the higher intensity of its restriction endonuclease fragments (see fig. 2).

Plasmids from methicillin-susceptible and $\mathrm{Gm}^{\mathrm{s}}$ strains SA19 and SA20 had restriction profiles distinct from all other strains examined (fig. 2a). It 
a

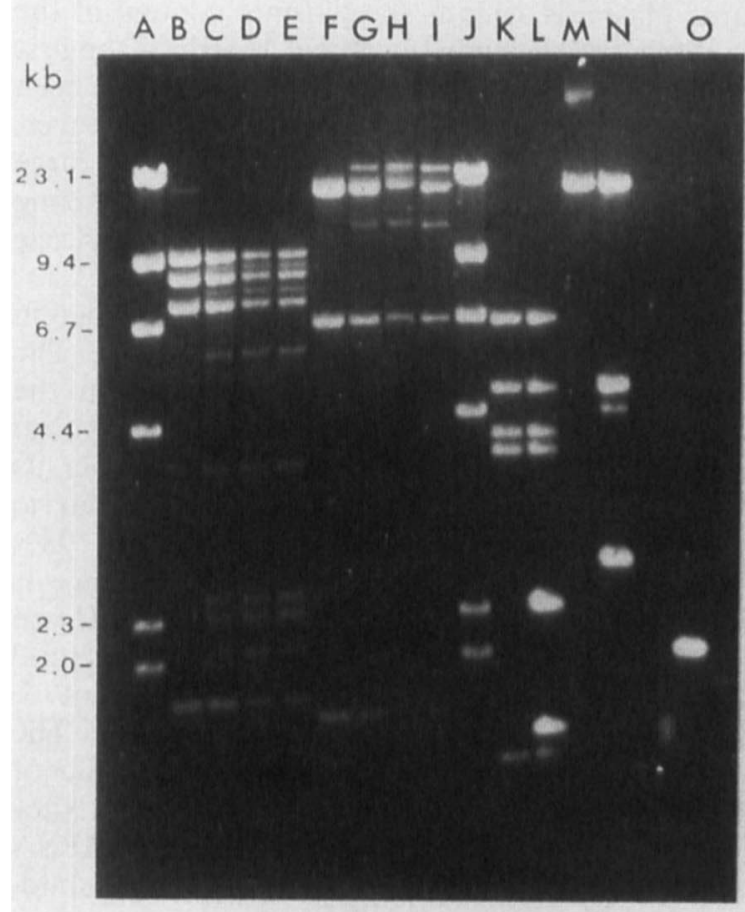

b

A B CDEFGHIJKLMN

Fig. 2. (a) Agarose 0.7\% gel electrophoresis of HindIII (lanes B-E) and PstI (lanes F-I) restriction endonuclease digests of purified plasmids from designated strains. Lanes A and J, $\lambda$ HindIII ; lanes B and F, strain SA1; lanes C and G, strain SA2; lanes D and H, strain SA 17; lanes E and I, strain SA18; lanes K and M, strain SA19; lanes L and N, strain SA20; lane 0, 2.1-kb DdeI fragment of pH13. (b) Gel a blotted to nitrocellulose and probed with nick-translated 2-1-kb DdeI fragment of pH13 coding for APH(2")AAC $\left(6^{\prime}\right)$ I. A-0-2-h exposure of autoradiograph; $0^{\prime}-15 \mathrm{~min}$ exposure of autoradiograph.

appeared from the restriction endonuclease analysis that they shared a common plasmid of $21 \cdot 1 \mathrm{~kb}$. SA20 also contained a small unique plasmid of $4.61 \mathrm{~kb}$.

The DNA fragments from restriction endonu-

Table III. Fragments generated by restriction endonuclease digestion of $S$. aureus strains SA1 $\left(\mathrm{Gm}^{\mathrm{s}}\right)$ and SA2 $\left(\mathrm{Gm}^{\mathrm{r}}\right)$

\begin{tabular}{|c|c|c|}
\hline $\begin{array}{l}\text { Restriction } \\
\text { enzyme }\end{array}$ & Strain & Size of fragments $(\mathrm{kb})^{*}$ \\
\hline HindIII & $\begin{array}{l}\text { SA1 } \\
\text { SA2 }\end{array}$ & $\begin{array}{l}9 \cdot 27,8 \cdot 2,7 \cdot 17,1 \cdot 76 \\
9 \cdot 27, \mathbf{8} \cdot 93,8 \cdot 2,7 \cdot 77,7 \cdot 17, \mathbf{5 \cdot 8}, \mathbf{3 \cdot 6 7}, \\
\mathbf{2 \cdot 4 3}, \mathbf{2 \cdot 2 4}, \mathbf{2 \cdot 0}, 1 \cdot 76\end{array}$ \\
\hline Pst $\mathrm{I}$ & $\begin{array}{l}\text { SA1 } \\
\text { SA2 }\end{array}$ & $\begin{array}{l}17 \cdot 0,6 \cdot 66,1 \cdot 58 \\
29 \cdot 5,16 \cdot 7,11 \cdot 34,6 \cdot 66,1 \cdot 58\end{array}$ \\
\hline
\end{tabular}

*Sizes in bold represent fragments from gentamicin resistance plasmids. clease digests (fig. 2a) were also probed with the 2-1-kb DdeI fragment of $\mathrm{pH} 13$. A $2 \cdot 5-\mathrm{kb}$ HindIII fragment of the $\mathrm{Gm}^{\mathrm{r}}$ plasmids hybridised with the probe (fig. $2 \mathrm{~b}$, lanes $\mathrm{C}, \mathrm{D}$ and $\mathrm{E}$ ), as did a $10 \cdot 8-\mathrm{kb}$ Pst I fragment (fig. 2B, lanes $\mathrm{G}, \mathrm{H}$ and I). The $\mathrm{Gm}^{\mathrm{s}}$ plasmids showed no homology with the $2 \cdot 1-\mathrm{kb}$ DdeI probe (fig. 2b, lanes B, F, K, L, M and N).

\section{Plasmid transfer and curing}

Transfer of gentamicin or penicillin resistance in this study could not be accomplished by the method of Forbes and Schaberg (1983), despite the successful transfer in a control mating between $S$. aureus UM899 and recipient $S$. aureus 879R4RF of gentamicin resistance as reported by Forbes and Schaberg (1983). Altering the ratio of recipient: donor or employing an overnight incubation of the mating mixture in filters did not result in a successful mating.

Curing of $\mathrm{Pc}^{\mathrm{r}}$ from MRSA strain SA1 could not 
be accomplished; however, $\mathrm{Gm}^{\mathrm{r}}$ MRSA strain SA2 was cured of gentamicin resistance at a rate of $4 \%$. The plasmid content of these cured strains $\left(\mathrm{Gm}^{\mathrm{s}}\right)$, along with strain SA2 $\left(\mathrm{Gm}^{\mathrm{r}}\right)$, were compared by electrophoresis on agarose gels, which were blotted to nitrocellulose and probed with the $\mathrm{Gm}^{\mathrm{r}}$ probe. The cured strains did not contain the $32 \cdot 8-\mathrm{kb}$ plasmid and did not hybridise to the probe. This is in contrast to the $32 \cdot 8-\mathrm{kb}$ plasmid of strain SA2, which did hybridise with the probe, and thus confirms the plasmid location of the gentamicinresistance determinant.

\section{Discussion}

Plasmid profiles are often used as epidemiological markers for nosocomial outbreaks of $S$. aureus (Townsend et al., 1984; Archer et al., 1985; Schaberg et al., 1985). S. aureus strains carry a variety of plasmids, many of which encode antibiotic resistance determinants. The plasmid analysis of $S$. aureus is generally stable, reproducible and is a reliable method for distinguishing $S$. aureus strains (Archer and Mayhall, 1983). However, the interpretation of results between studies can be misleading. As can be seen from our data, different buffer systems resulted in different banding patterns. With TA buffer more than one molecular form of each plasmid was evident, while with TBE buffer the individual plasmid bands co-migrated and were, therefore, obscured. Several workers have used either tris-borate buffers (Archer and Johnston, 1983; Goering and Ruff, 1983; Lyon et al., 1983; Dunkle and Sippel, 1984) or tris-acetate buffers (Kozarsky et al., 1986). Tris-acetate is a higher ionic strength buffer and seems to result in better separation of large molecules, but determination of the number of different plasmids is difficult with this buffer. Researchers who have employed plasmid patterns to differentiate $S$. epidermidis, have reported similar difficulties (Archer et al., 1984; Parisi et al., 1986); these have included problems with chromosomal DNA obscuring plasmid bands and with the variable conversion of plasmid DNA to open circular, closed circular and linear forms. These difficulties confirm the need for careful analyses when comparing plasmid profiles. The mobility of large molecules $(<20 \mathrm{~kb})$ in agarose gels is independent of size (Degennes, 1971). Molecules of this size no longer sieve through the gel pores during electrophoresis but travel along their long axes at the same speed. Reverse or pulsed field gel electrophoresis involves cycles of forward and reverse electrical field pulses which result in size separation because small molecules change direction faster (Carle et al., 1986). Thus, it is a convenient tool for analysing large plasmids such as the plasmid content of the $S$. aureus in this study (fig. 1, gel 3). This is the first time that reverse field electrophoresis has been employed to analyse $S$. aureus plasmids. However, because of the anomalous migration of large plasmids on agarose gels, accurate plasmid sizing should be completed by restriction endonuclease analysis.

Gentamicin resistance in $S$. aureus is encoded in plasmids which vary in size considerably. The $36.5-\mathrm{kb} \mathrm{Gm}^{\mathrm{r}}$ plasmid in this study falls within the size ranges previously reported $(18-57 \mathrm{~kb}$ ) (Lyon et al., 1983; Lyon and Skurray, 1987), however its restriction endonuclease profile is not similar to those previously reported (Jaffe et al., 1982; Schaberg et al., 1985). Gentamicin resistance is encoded on a transposon in some instances (Lyon et al., 1984), thereby explaining the structural diversity of plasmids in gentamicin-resistant $S$. aureus strains (Lyon and Skurray, 1987). The similarity of the restriction endonuclease profiles of the $\mathrm{Gm}^{\mathrm{r}}$ strains in this study indicates that they originated from a common source. The $\mathrm{Gm}^{\mathrm{s}}$ MRSA strain, which carried a common cryptic plasmid, were also probably of similar origin.

The $36 \cdot 5-\mathrm{kb} \mathrm{Gm}^{\mathrm{r}}$ plasmid examined in this study appears to bear no similarity with respect to size or restriction endonuclease profile to those studied extensively in the USA (Jaffe et al., 1982) or Australia (Lyon et al., 1983).

Transfer of the $\mathrm{Gm}^{\mathrm{r}}$ plasmid could not be accomplished by a filter mating technique. Either the $\mathrm{Gm}^{\mathrm{r}}$ plasmid from strain SA2 lacks the tra phenotype or has a mutated tra gene. Another explanation could be that the transfer is donor or host strain dependent, a phenomenon which has been reported previously (Goering and Ruff, 1983). American $\mathrm{Gm}^{\mathrm{r}} S$. aureus plasmids have been transferred from $S$. aureus to $S$. aureus and from $S$. epidermidis to $S$. aureus (McDonnell et al., 1983). Some Australian $\mathrm{Gm}^{\mathrm{r}}$ plasmids (Lyon et al., 1983, 1984) are non-conjugal, whereas others could be routinely transferred by mixed culture matings (Townsend et al., 1984). Conjugal plasmid transfer among MRSA strains seems to be a variable trait as far as $\mathrm{Gm}^{\mathrm{r}}$ plasmids are concerned and the Canadian plasmids described in this study were nontransferable.

As transfer was not achieved, identification of our specific $\mathrm{Gm}^{\mathrm{r}}$ plasmid and the resistance determinant on the plasmids was accomplished by probing with the APH $\left(2^{\prime \prime}\right)-\mathrm{AAC}\left(6^{\prime}\right) \mathrm{I}$ sequence which was carried on a $2 \cdot 1-\mathrm{kb}$ DdeI fragment from 
pH 13. A $2 \cdot 5-\mathrm{kb}$ HindIII fragment of the $\mathrm{Gm}^{\mathrm{r}}$ plasmids in our study hybridised with this probe. A similar sized HindIII fragment was associated with gentamicin resistance in both American (Jaffe et al., 1982) and Australian (Lyon et al., 1983) $\mathrm{Gm}^{\mathrm{r}}$ plasmids. This fragment has also been characterised on a 4.7-kb transposon (Lyon et al., 1984) in Australian isolates but not American isolates (Archer and Johnston, 1983), possibly because the inverted repeats flanking the $\mathrm{Gm}^{\mathrm{r}}$ determinant were shorter than those in Australian strains (Lyon and Skurray, 1987). The $2 \cdot 5-\mathrm{kb}$ HindIII fragment has been characterised on different $\mathrm{Gm}^{\mathrm{r}} S$. aureus plasmids around the world, thereby inferring an

\section{REFERENCES}

Archer G L, Johnston J L 1983 Self-transmissible plasmids in staphylococci that encode resistance to aminoglycosides. Antimicrobial Agents and Chemotherapy 24: 70-77.

Archer G L, Mayhall C G 1983 Comparison of epidemiological markers used in the investigation of an outbreak of methicillin-resistant Staphylococcus aureus infections. Journal of Clinical Microbiology 18 : 395-399.

Archer G L, Karchmer A W, Vishniavsky N, Johnston J L 1984 Plasmid-pattern analysis for the differentiation of infecting from noninfecting Staphylococcus epidermidis. Journal of Infectious Diseases 149: 913-920.

Archer G L, Dietrick, D R, Johnston J L 1985 Molecular epidemiology of transmissible gentamicin resistance among coagulase-negative staphylococci in a cardiac surgery unit. Journal of Infectious Diseases 151 : 243-251.

Birnboim H C, Doly J 1979 A rapid alkaline extraction procedure for screening recombinant plasmid DNA. Nucleic Acids Research 7: 1513-1523.

Borowski J, Kamienska K, Rutecka I 1964 Methicillin-resistant staphylococci. British Medical Journal 1 : 983.

Buckwold F J, Albritton W L, Ronald A R, Lertzman J, Henriksen R 1979 Investigations of the occurrence of gentamicin-resistant Staphylococcus aureus. Antimicrobial Agents and Chemotherapy 15: 152-156.

Carle G F, Frank M, Olson M V 1986 Electrophoretic separations of large DNA molecules by periodic inversion of the electric field. Science 232: 65-68.

Degennes P G 1971 Reptation of a polymer chain in the presence of fixed obstacles. Journal of Chemical Physics 55: 572-579.

Dickgiesser N, Krieswirth B N 1986 Determination of aminoglycoside resistance in Staphylococcus aureus by DNA hybridization. Antimicrobial Agents and Chemotherapy 29: 930-932.

Dillon J R, Nasim A, Nestmann E R (eds) 1985 Recombinant DNA methodology. John Wiley and Sons, New York.

Dunkle L M, Sippel J C 1984 Rapid microprocedure for extraction of plasmid DNA from Staphylococcus aureus. Journal of Infectious Diseases 149: 921-923.

Forbes B A, Schaberg D R 1983 Transfer of resistance plasmids from Staphylococcus epidermidis to Staphylococcus aureus: evidence for conjugative exchange of resistance. Journal of Bacteriology 153: 627-634.

Goering R V, Ruff E A 1983 Comparative analysis of conjugative plasmids mediating gentamicin resistance in Staphylococcus aureus. Antimicrobial Agents and Chemotherapy 24:450-452. evolutionary relationship between these plasmids with respect to the acquisition of gentamicin resistance. Although the plasmids carrying the $\mathrm{Gm}^{\mathrm{r}}$ determinant varied among MRSA strains, the mechanism of $\mathrm{Gm}^{\mathrm{r}}$ in this study is similar to that observed in other parts of the world.

This work was supported in part by supplementary funding to the Bureau of Microbiology by the Government of Canada in support of the National Biotechnology Strategy. L.-K. Ng was supported by a Medical Research Council of Canada Postdoctoral Fellowship. We thank C. Dixon, M. Dugal and A. P. H. McLean, Royal Victoria Hospital, Montréal for initially identifying patients infected or colonised by outbreak strains, and Drs D. Schaberg and R. P. Novick for $S$. aureus mating strains and Dr B. Kreiswirth for providing plasmid $\mathrm{pH} 13$.

Jaffe H W, Sweeney H M, Weinstein R A, Kabins S A, Nathan C, Cohen S 1982 Structural and phenotypic varieties of gentamicin resistance plasmids in hospital strains of Staphylococcus aureus and coagulase-negative staphylococci. Antimicrobial Agents and Chemotherapy 21 : 773-779.

Kayser F M, Mak T M 1972 Methicillin-resistant staphylococci. American Journal of the Medical Science 264: 197-205.

King K, Brady L, Thomson M, Harkness J L 1982 Antibioticresistant staphylococci in a teaching hospital. Medical Journal of Australia 2: 461-465.

Kozarsky P E, Rimland D, Terry P M, Wachsmuth K 1986 Plasmid analysis of simultaneous nosocomial outbreaks of methicillin-resistant Staphylococcus aureus. Infection Control 7: $577-581$.

Kreiswirth B N, McGeer A, Simon A, Poor R, Love D 1988 Evaluation of variable gene probes to study an outbreak of methicillin-resistant Staphylococcus aureus (MRSA). Abstracts of the 88th Meeting of the American Society for Microbiology, Miami, FL, Abstract no. L5, p 411.

Lyon B R, May J W, Skurray R A 1983 Analysis of plasmids in nosocomial strains of multiple-antibiotic-resistant Staphylococcus aureus. Antimicrobial Agents and Chemotherapy 23: $817-826$.

Lyon B R, May J W, Skurray R A 1984 Tn4001: A gentamicin and kanamycin resistance transposon in Staphylococcus aureus. Molecular and General Genetics 193: 554-556.

Lyon B R, Skurray R A 1987 Antimicrobial resistance of Staphylococcus aureus: genetic basis. Microbiological Reviews 51 : 88-134.

Maniatis T, Fritsch E F, Sambrook J 1982 Molecular cloning: a laboratory manual. Cold Spring Harbor Laboratory, New York.

McDonnell R W, Sweeney H M, Cohen S 1983 Conjugal transfer of gentamicin resistance plasmids intra- and interspecifically in Staphylococcus aureus and Staphylococcus epidermidis. Antimicrobial Agents and Chemotherapy 23: 151-160.

National Committee for Clinical Laboratory Standards 1984 Performance standards for antimicrobial disk susceptibility testing, 3rd edn. Approved standard M2-A3, vol. 4, National Committee for Clinical Laboratory Standards. Vilianova, PA.

Ng L K, Stiles M E, Taylor D E 1987 DNA probes for identification of tetracycline resistance genes in Campylobacter species isolated from swine and cattle. Antimicrobial Agents and Chemotherapy 31 : 1669-1674.

Novick R 1967 Properties of a cryptic high-frequency transducing phage in Staphylococcus aureus. Virology 33: 155-166. 
Ogden R C, Adams D A 1987 Electrophoresis in agarose and acrylamide gels. Methods in Enzymology 152: 61-87.

O'Toole R D, Drew W L, Dahlgren B J, Beaty H N 1970 An outbreak of methicillin-resistant Staphylococcus aureus infection: observations in hospital and nursing home. Journal of the American Medical Association 213: 257-263.

Parisi J T, Lampson B C, Hoover D L, Knan J A 1986 Comparison of epidemiological markers for Staphylococcus aureus. Journal of Clinical Microbiology 24: 56-60.

Parker M T, Hewitt J H 1970 Methicillin-resistance in Staphylococcus aureus. Lancet 1: 800-804.

Perceval A, McLean A J, Wellington C V 1976 Emergence of gentamicin resistance in Staphylococcus aureus. Medical Journal of Australia 2: 74.

Price E H, Brain A, Dickson J A S 1980 An outbreak of infection with a gentamicin and methicillin resistant Staphylococcus aureus in a neonatal unit. Journal of Hospital Infection 1: 221-228.

Rouch D A, Byrne M E, Kong Y C, Skurray R A 1987 The aacA-aphD gentamicin and kanamycin resistance determinant of Tn4001 from Staphylococcus aureus: expression and nucleotide sequence analysis. Journal of General Microbiology 133: 3039-3052.

Rountree P M, Beard M A 1968 Hospital strains of Staphylococcus aureus, with particular reference to methicillin-resistant strains. Medical Journal of Australia 2: 1163-1168.

Schaberg D R, Power G, Betzold J, Forbes B A 1985 Conjugative $\mathbf{R}$ plasmids in antimicrobial resistance of Staphylococcus aureus causing nosocomial infections. Journal of Infectious Diseases 152: 43-49.
Shannon K, Phillips I 1982 Mechanisms of resistance to aminoglycosides in clinical isolates. Journal of Antimicrobial Chemotherapy 9: 91-102.

Shanson D C, Kensit J G, Duke R 1976 Outbreak of hospital infection with a strain of Staphylococcus aureus resistant to gentamicin and methicillin. Lancet 2: 1347-1348.

Southern E 1975 Detection of specific sequences among DNA fragments separated by gel electrophoresis. Journal of Molecular Biology 98: 503-517.

Thornsberry C 1984 Methicillin-resistant (hetero-resistant) staphylococci. The Antimicrobic Newsletter 1 : 43-50.

Townsend D E, Ashdown N, Greed L C, Grubb W B 1984 Analysis of plasmids mediating gentamicin resistance in methicillin-resistant Staphylococcus aureus. Journal of Antimicrobial Chemotherapy 13: 347-352.

Trees D L, Iandolo J J 1988 Identification of a Staphylococcus aureus transposon (Tn4291) that carries the methicillin resistance gene(s). Journal of Bacteriology 170 : 149-154.

Varaldo P E et al. 1984 Identification, clinical distribution, and susceptibility to methicillin and 18 additional antibiotics of clinical Staphylococcus isolates: nationwide investigation Italy. Journal of Clinical Microbiology 19: 838-843.

Wenzel R P (editorial) 1982 The emergence of methicillinresistant Staphylococcus aureus. Annals of Internal Medicine 97: 440-442.

Zoller M, Pielak G, Atkinson T, Gillam S, Smith M 1985 Manual for "Workshop for advanced techniques in molecular biology", Department of Biochemistry, University of British Columbia Vancouver, p. 73. 